\title{
Evaluation of the water and sediment quality of a lotic water-body in the western coastal region of Sri Lanka using Rapid Bioassessment Protocol II (RBP II) of benthic macroinvertebrates
}

\author{
W.M.D.N. Wijeyaratne* and K.M.B.P.P. Kalaotuwawe \\ Department of Zoology and Environmental Management, University of Kelaniya, Kelaniya 11600 , \\ Sri Lanka \\ *Corresponding Author (dimuthu.wijeyaratne@kln.ac.lk) \\ (iD) http://orcid.org/0000-0002-3502-0410
}

\begin{abstract}
The biotic indices used in Rapid Bioassessment Protocol II (RBP II) developed by United States Environmental Protection Agency was used to assess the feasibility of using benthic macroinvertebates as bio-indicators for monitoring water and sediment quality in Ja-Ela stream, which is a lotic water body in the western coastal region of Sri Lanka. Five study sites to cover the entire length of the stream, which are in five different fringing land uses (undisturbed site, agricultural site, industrial discharge receiving site, densely populated urban site and a site close to the mouth of the stream) were sampled for water and sediment quality parameters and benthic macroinvertebrates from April to October 2015. Shannon-Weiner diversity index $\left(\mathrm{H}^{\prime}\right)$, Hilsenhoff Family Biotic index (FBI), Taxa richness (TRI), and Ehemeroptera, Plecoptera and Trichoptera (EPT) index were calculated for each site. Results indicated significant spatial variations in $\mathrm{BOD}_{5}, \mathrm{COD}$, visibility, nitrate concentration and total phosphorus concentrations in the water, and total organic carbon content and particle size distribution in sediments. The highest mean values for $\mathrm{H}^{\prime}$ (2.38), TR (13.6) and EPT (6.2) were recorded from the undisturbed site. Significantly higher FBI values are recorded from the industrial discharge receiving site (6.97) and the urban site (6.81), indicating that they are the most polluted sites with higher degree of organic pollution than other sites. These biotic index values showed significant correlations with sediment and water quality characteristics of the study sites $\left(\mathrm{R}^{2}\right.$ $>0.5$, $\mathrm{p}<0.05)$ The H', EPT, FBI and TR values for benthic macro-invertebrate community showed that the upstream portion of this stream is habitable to pollution sensitive taxa, while the downstream areas close to its opening to Negombo estuary are habitable by pollution tolerant taxa. Results of the present study identified the RBP II as a possible bio monitoring protocol to reflect the water and sediment quality in the Ja-Ela stream.
\end{abstract}

Keywords: Biotic indices, benthic macroinvertebrates, bioindicators, aquatic pollution, urban stream

\section{INTRODUCTION}

Water and sediment quality monitoring of natural water bodies is widely applied to identify the influences of point and non-point source pollution in aquatic ecosystems. Most of these monitoring programs involve measuring of physico-chemical parameters of aquatic ecosystems. However, the biotic component of an aquatic system is of equal importance in determining the level of pollution, as these organisms are continuously exposed to the substances of their living medium during most parts of their life cycle (Wijeyaratne and Pathiratne 2006).
Rapid Bioassessment Protocols (RBP) developed by the US Environmental Protection Agency (USEPA) (Barbour et al. 1999) enable the researchers to use the biological data to infer watershed conditions and to compare reference sites with the areas of concern (Guruge et al. 2000). RBPs are popular bio-monitoring protocols due to their efficiency and cost effectiveness. Currently the USEPA encourages the use of RBPs because they provide quick and valid results while being cost effective, time efficient, and minimally invasive (Barbour et al. 1999).

The USEPA has developed five Rapid Bioassessment Protocols (RBP I, RBP II, RBP III,

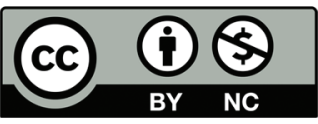

This work is licensed under a Creative Commons Attribution-NonCommercial 4.0 International License. 
RBP IV and RBP V) of which the first three are based on macroinvertebrates and the latter two are based on fish (Mandaville 2002). The complexity of the protocol increases with the RBP number, RBP I being the simplest (Barbour et al. 1999).

The macroinvertebrate survey in RBP II and RBP III are the most commonly used methods because it requires little expertise and equipment (Goldstein 2011). In RBP II, the results of macroinvertebrate surveys are interpreted using several biotic indices. Macroinvertebrate indices often describe a taxon in terms of its tolerance to prevailing environmental conditions. When using RBPs to assess water quality, multiple indices must be used to quantify the water quality as each index strongly reflects different characteristics. The minimum number of indices recommended is four (Barbour et al. 1999). The most common indices used to evaluate stream water quality under RBP II are the Taxa Richness, Ephemeroptera, Plecoptera, and Trichoptera (EPT) index, Ratio of EPT and Chironomid abundance, Modified Hilsenhoff Family Biotic Index (HFBI) and Percent contribution of dominant taxa (Goldstein 2011).

RBP has been widely used in many countries including USA, Australia, Poland, Turkey, Brazil and Nigeria as a tool to assess stream water quality in order to identify sediment and pollutant sources (Chessman et al. 1995, 2005; Emre and Nasiru 2005; Uyanik et al. 2005; Lewin et al. 2013; Goldstein 2011). However, this RBP technique is still less popular in most countries in the world (Goldstein 2011; Kripa et al. 2013).

In Sri Lanka published research on biotic indices of benthic communities to assess the environmental conditions, is rare. However, diversity indices of benthic macro invertebrate communities have been used in several studies in order to monitor the environmental conditions (Gamlath and Wijeyaratne 1997; Dahanayaka and Wijeyaratne 2006; Perera et al. 2012; Idroos and Manage 2012; Madhushanka et al. 2014). In addition, many studies have concentrated on assessment of physicochemical parameters in the aquatic systems of Sri Lanka in order to identify the source and sink areas of pollutants (Sangakkara and Wijeyaratne 2015; Wijeyaratne 2016). Commonly used biotic indices in RBP II technique are accompanied by multivariate approaches that provide information about the spatial and temporal variations of the environmental characteristics of the aquatic environment (Lewin et al. 2013; Goldstein 2011). Therefore, there is an increasing need for analyzing the suitability of RBP technique for Sri Lankan aquatic systems.

The present study was conducted with the objective of assessing the applicability of RBP II biotic indices and diversity indices of macroinvertebrates for monitoring the spatial and temporal variation of water quality and pollution level in the Ja-Ela stream in the western coastal region in the wet zone of Sri Lanka which runs through different types of land use areas.

\section{MATERIALS AND METHODS}

\section{Study area}

Ja-Ela stream, which is about $12 \mathrm{~km}$ in length is an urban freshwater stream located in the western coastal region of the wet zone of Sri Lanka ( $7^{\circ} 5^{\prime} 55^{\prime \prime}$ $\mathrm{N}$ and $79^{\circ} 51^{\prime} 30^{\prime \prime} \mathrm{E}$ ). Although small in length, it was selected for this study as it runs through different land use areas (Fig. 1).

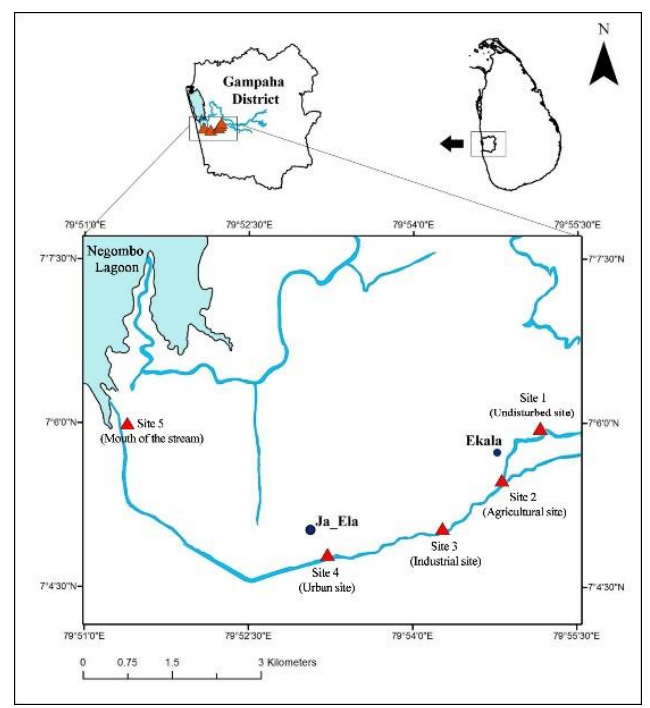

Fig. 1 The five study sites in the Ja Ela canal

Ja-Ela stream is the main supply of irrigation water within the area. Residents who live in lands adjoining the stream use its water for their daily activities such as washing, bathing and also for subsistence fishing. Due to anthropogenic activities of nearby residents, large amounts of solid waste, waste water and sewage are added into the stream, which lead to the degradation of water quality. JaEla stream is bordered by lands with many different 
land uses including agriculture, industries, urbanized areas, rural areas and densely vegetated areas. Most upstream areas of the stream are associated with highly vegetated lands where human settlements and human interventions are minimum.

Five sites (site 1-5) in the Ja-Ela stream were selected to cover the entire length of the stream considering the land uses. Site 1 ( $7^{\circ} 2^{\prime} 52.69^{\prime \prime}$, $79^{\circ} 56^{\prime} 59.37$ "E) was characterized by nearly pristine environmental conditions with minimum human influences. This site was located in the upstream most part of the stream and the area was surrounded by scrubs that profuse with trees and shrubs. Human settlements were far away from the site and this was considered as the reference site. Site $2\left(7^{\circ}\right.$ $\left.2^{\prime} 54.07 " \mathrm{~N}, 79^{\circ} 56^{\prime} 37.87^{\prime \prime E}\right)$ was associated with paddy cultivated areas and site $3\left(7^{\circ} 2 ' 58.01 " \mathrm{~N}\right.$, $\left.79^{\circ} 5628.70 " \mathrm{E}\right)$ received industrial waste water through discharge outlets. Site 4 ( $7^{\circ} 3^{\prime} 6.17^{\prime \prime} \mathrm{N}$, $79^{\circ} 56^{\prime} 19.44 " \mathrm{\prime}$ ) was located at the Ja-Ela town which is highly urbanized and populated. Waste water from many places such as restaurants, commercial buildings and houses were discharged in this area. Site 5 ( $\left.7^{\circ} 3{ }^{\prime} 20.99^{\prime \prime} N, 7^{\circ} 56^{\prime} 20.68^{\prime \prime} \mathrm{E}\right)$ was the downstream most site and it was located near the mouth of the stream.

\section{Water and sediment quality parameters}

From each site water samples and sediments samples were collected for the water quality analysis, sediment quality analysis and benthic macroinvertebrate diversity determination. Sampling was carried out once in 6 weeks for a period of 7 months from April to October in 2015.

At each sampling site, water $\mathrm{pH}$, water temperature, conductivity, total dissolved solids (TDS) and sediment $\mathrm{pH}$ were measured in-situ using a calibrated digital multi parameter (YSI Environmental Model-556 MPS). Dissolved oxygen concentration (DO) was measured using DO meter (HQ 40b model-Hach). Visibility was recorded using a Secchi disk. The biological oxygen demand at 5 days after incubation $\left(\mathrm{BOD}_{5}\right)$, Chemical oxygen demand (COD), nitrate concentration and total and dissolved phosphorus concentrations were measured using the methods described by APHA (1992).

Sediment organic matter content was measured in the laboratory using the loss on ignition method and the percentage sand, silt and clay contents of the sediments were measured using the sedimentation jar. Water and sediment quality parameters were measured in triplicate within a $1 \mathrm{~m}^{2}$ area and averaged for each sampling site.

\section{Benthic macroinvertebrates.}

Benthic macroinvertebrate sampling was carried out using the kick sampling method and Peterson grab sampling method (Dahanayake and Wijeyaratne 2006). The collected samples were preserved in 5\% Rose Bengal solution on site and were transported to the laboratory. In the laboratory at the University of Kelaniya, samples were subjected to wet sieving through $4 \mathrm{~mm}, 2 \mathrm{~mm}$ and $1 \mathrm{~mm}$ mesh sieves to separate macrobenthic invertebrates. The organisms retained in each sieve were collected and preserved in $10 \%$ formalin and after a week they were transferred into $10 \%$ ethyl alcohol to prevent dehydration as described by Murugesan and Khan (2007). Macroinvertebrates were identified to family level using keys given by Fernando and Weerawardhena (2002). The number of individuals of each taxon and the number of families at each sampling site were counted.

The diversity of macroinvertebrates at each site was calculated using Shannon-Weiner index $\left(\mathrm{H}^{\prime}\right)$, Family Biotic Index, EPT Index, Ratio of EPT to Chironomidae and Taxa Richness Index.

Shannon-Wiener Diversity Index (H') was calculated as;

$$
H^{\prime}=-\sum_{\mathrm{i}=1}^{\mathrm{s}} \mathrm{P}_{\mathrm{i}}\left(\log _{2} \mathrm{P}_{\mathrm{i}}\right)
$$

where $P_{i}$ is the proportion of individuals in the $i^{\text {th }}$ taxon of the community and $s$ is the total number of taxa in the community. As the number and distribution of taxa (biotic diversity) within the community increases, so does the value of $\mathrm{H}^{\text {' }}$ (Mandaville 2002).

The Biotic Index originally developed by Hilsenhoff (1988) was modified to the family-level with tolerance values ranging from 0 (very intolerant) to 10 (highly tolerant) based on their tolerance to organic pollution, creating the Family Biotic Index (FBI; Plafkin et al. 1989; Bode et al. 1991).

FBI was calculated as:

$$
\mathrm{FBI}=\sum \frac{\mathrm{x}_{\mathrm{I}} \mathrm{t}_{\mathrm{i}}}{\mathrm{n}}
$$

where $x_{i}$ is the number of individuals in the $\mathrm{i}^{\text {th }}$ taxon, $t_{i}$ is the tolerance value of the $\mathrm{i}^{\text {th }}$ taxon (Table 1 ), and $\mathrm{n}$ is the total number of organisms in the sample. 
Table 1 Tolerance Values for macroinvertebrates for application in the Modified Family Biotic Index and other metrics (Source: Hilsenhoff 1988).

\begin{tabular}{|c|c|c|c|}
\hline Phylum/Family & Tolerance values & Phylum/Family & Tolerance values \\
\hline Annelida & & Arthropoda & \\
\hline Tubificidae & 8 & Tabanidae & 6 \\
\hline Tubifex sp & 8 & Chironomus sp & 0 \\
\hline Naididae & 8 & Ceratopogonidae & 6 \\
\hline Species 1 & 8 & Biting midge larvae & 6 \\
\hline Naididae & 0 & Order- Ephemeroptera & 4 \\
\hline Species 2 & 8 & Family- Baetidae & 4 \\
\hline & & Order- Ephemeroptera & 2 \\
\hline Mollusca & & Family- Leptophlebiidae & 2 \\
\hline Pilidae & 8 & Order- Odonata & 0 \\
\hline Pila globosa & 8 & Family- Coenagrionidae & 9 \\
\hline Thiaridae & 6 & Order- Plecoptera & 1 \\
\hline Melanoides tuberculata & 6 & Family- Perlidae & 1 \\
\hline Thiaridae & & Order-Trichoptera & \\
\hline Faunus ater & 6 & Family- Hydropsychidae & 4 \\
\hline Lymnaeidae & & Order-Trichoptera & \\
\hline Lymnaea pinguis & 6 & Family- Helicopsychidae & 3 \\
\hline Planorbidae & & Order - Coleoptera & 4 \\
\hline Indoplanorbis exustus & 7 & Family - Psephenidae & 4 \\
\hline $\begin{array}{l}\text { Paludestrinidae } \\
\text { Bithvnia inconspicug }\end{array}$ & 6 & & \\
\hline
\end{tabular}

The Ephemeroptera, Plecoptera, and Trichoptera (EPT) index displays the taxa richness within the insect groups which are considered to be sensitive to pollution. The EPT index is equal to the total number of families represented within these three orders in the sample.

Taxa Richness (TR) equals the total number of taxa represented within the sample. The healthier the community is, the greater the number of taxa found within that community.

These indices were calculated for all 5 sampling sites at each sampling occasion and data were averaged over time for 5 study sites. Average diversity index values and biotic index values were plotted to show the spatial variation of index values among the five sampling sites.

\section{Statistical analysis}

After confirming the normality using Anderson Darling test, the data were analyzed using one way ANOVA followed by Tukey's pairwise comparison to determine the significance of the spatial and temporal variation of selected water quality and sediment quality parameters in the Ja-Ela stream. The values of diversity indices used in RBP II protocol for each site, calculated for different sampling days were also confirmed for normality using Anderson Darling test and subjected to one way ANOVA followed by Tukey's pairwise comparison.

Principal Component Analysis (PCA) was applied to determine water and sediment quality parameters and diversity and biotic indices that describe the distribution of benthic macro invertebrates in the Ja-Ela stream. Regression analysis between PC1 score, PC2 score and Shannon-Weiner diversity index, Family Biotic index, Taxa richness and EPT index were calculated to determine the linear relationship between them. MINITAB 14 statistical software package was used in the statistical analysis. 


\section{RESULTS}

The spatial variation mean \pm standard deviation (SD) of each of the water quality parameters of the study sites during the sampling period is given in Table 2. The temporal variation of mean \pm SD of each of the water quality parameters of the study sites during the sampling period is given in Table 3. Significant spatial variations were observed in electrical conductivity, total dissolved solids, $\mathrm{BOD}_{5}, \mathrm{COD}$, nitrate content, total phosphorus concentrations and visibility $(p<0.05$; Table 2$)$. The spatial variation of mean \pm SD of each of the sediment quality parameters of the study sites during the sampling period is given in Table 4 . The temporal variation of mean $\pm \mathrm{SD}$ of each of the sediment quality parameters of the study sites during the sampling period is given in Table 5 . Percentage total organic carbon, percentage sand content, percentage clay content and percentage silt content showed significant spatial variation among the study sites $(\mathrm{p}<0.05)$, while the variation of other parameters were not significant $(\mathrm{p}>0.05$; Table 4). There was no significant temporal variation in the water and sediment quality parameters (Table 3 and Table 5; one way ANOVA, $\mathrm{p}>0.05)$.

Table 2 Spatial variation of water quality parameters in the study sites of the Ja-Ela stream $(n=9)$. Results are presented as mean \pm standard deviation. Different superscripts in each row indicate statistically significant differences (One way ANOVA, Tukey's pairwise test; $p<0.05$ ). Site 1: Undisturbed site; Site 2: Agricultural site; Site 3: Industrial site; Site 4: Urban site; Site 5: Mouth of the stream

\begin{tabular}{lccccc}
\hline & Site 1 & Site 2 & Site 3 & Site 4 & Site 5 \\
\hline $\mathrm{pH}$ & $6.5 \pm 0.3^{\mathrm{a}}$ & $6.7 \pm 0.3^{\mathrm{a}}$ & $6.7 \pm 0.2^{\mathrm{a}}$ & $6.5 \pm 0.2^{\mathrm{a}}$ & $6.8 \pm 0.1^{\mathrm{a}}$ \\
Temperature $\left({ }^{\circ} \mathrm{C}\right)$ & $30.3 \pm 0.6^{\mathrm{a}}$ & $30.5 \pm 0.8^{\mathrm{a}}$ & $30.4 \pm 0.8^{\mathrm{a}}$ & $31.1 \pm 1.1^{\mathrm{a}}$ & $30.1 \pm 0.9^{\mathrm{a}}$ \\
$\mathrm{EC}(\mu \mathrm{S} / \mathrm{cm})$ & $89.3 \pm 4.9^{\mathrm{a}}$ & $92.9 \pm 5.3^{\mathrm{a}}$ & $120.5 \pm 4.9^{\mathrm{b}}$ & $310.9 \pm 5.7^{\mathrm{c}}$ & $100.3 \pm 6.4^{\mathrm{b}}$ \\
$\mathrm{TDS}(\mathrm{mg} / \mathrm{L})$ & $54.82 \pm 3.1^{\mathrm{a}}$ & $57.72 \pm 3.9^{\mathrm{a}}$ & $66.92 \pm 5.9^{\mathrm{a}}$ & $345.9 \pm 3.9^{\mathrm{b}}$ & $68.6 \pm 5.7^{\mathrm{a}}$ \\
DO $(\mathrm{mg} / \mathrm{L})$ & $4.3 \pm 0.1^{\mathrm{a}}$ & $5.4 \pm 0.08^{\mathrm{a}}$ & $4.9 \pm 0.05^{\mathrm{a}}$ & $3.9 \pm 0.09^{\mathrm{a}}$ & $4.7 \pm 0.1^{\mathrm{a}}$ \\
BOD5 $(\mathrm{mg} / \mathrm{L})$ & $3.3 \pm 0.7^{\mathrm{a}}$ & $3.58 \pm 0.4^{\mathrm{a}}$ & $5.88 \pm 0.5^{\mathrm{b}}$ & $7.4 \pm 0.7^{\mathrm{c}}$ & $4.04 \pm 0.6^{\mathrm{a}}$ \\
$\mathrm{COD}(\mathrm{mg} / \mathrm{L})$ & $33.6 \pm 2.3^{\mathrm{a}}$ & $51.8 \pm 11.7^{\mathrm{b}}$ & $114.4 \pm 5.7^{\mathrm{c}}$ & $71.32 \pm 9.2^{\mathrm{b}}$ & $59.44 \pm 4.5^{\mathrm{b}}$ \\
Nitrate $(\mathrm{mg} / \mathrm{L})$ & $0.8 \pm 0.04^{\mathrm{a}}$ & $1.8 \pm 0.2^{\mathrm{b}}$ & $0.9 \pm 0.1^{\mathrm{a}}$ & $0.7 \pm 0.1^{\mathrm{a}}$ & $0.9 \pm 0.05^{\mathrm{a}}$ \\
Dissolved Phosphorus $(\mathrm{mg} / \mathrm{L})$ & $0.2 \pm 0.07^{\mathrm{a}}$ & $0.2 \pm 0.08^{\mathrm{a}}$ & $0.2 \pm 0.07^{\mathrm{a}}$ & $0.2 \pm 0.08^{\mathrm{a}}$ & $0.2 \pm 0.08^{\mathrm{a}}$ \\
Total Phosphorus $(\mathrm{mg} / \mathrm{L})$ & $0.24 \pm 0.02^{\mathrm{a}}$ & $0.68 \pm 0.05^{\mathrm{b}}$ & $0.55 \pm 0.03^{\mathrm{c}}$ & $0.28 \pm 0.04^{\mathrm{c}}$ & $0.31 \pm 0.06^{\mathrm{c}}$ \\
Visibility $(\mathrm{cm})$ & $101.4 \pm 9.2^{\mathrm{a}}$ & $78.5 \pm 4.3^{\mathrm{b}}$ & $66.6 \pm 7.8^{\mathrm{b}}$ & $77.1 \pm 1.9^{\mathrm{b}}$ & $74.1 \pm 4.1^{\mathrm{b}}$ \\
\hline
\end{tabular}


Table 3 Temporal variation of water quality parameters in the study sites of the Ja-Ela stream $(n=9)$. Results are presented as mean \pm standard deviation. Similar superscripts in each row indicate that there was no statistically significant temporal variation in the water quality parameters throughout the study period (One way ANOVA, Tukey’s pairwise test; $\mathrm{p}<0.05$ )

\begin{tabular}{lccccc}
\hline & April & May & July & August & October \\
\hline $\mathrm{pH}$ & $6.59 \pm 0.2^{\mathrm{a}}$ & $6.48 \pm 0.3^{\mathrm{a}}$ & $6.53 \pm 0.2^{\mathrm{a}}$ & $6.45 \pm 0.1^{\mathrm{a}}$ & $6.52 \pm 0.1^{\mathrm{a}}$ \\
Temperature $\left({ }^{\circ} \mathrm{C}\right)$ & $30.4 \pm 0.2^{\mathrm{a}}$ & $30.5 \pm 0.8^{\mathrm{a}}$ & $30.6 \pm 0.9^{\mathrm{a}}$ & $31.2 \pm 0.9^{\mathrm{a}}$ & $30.2 \pm 0.8^{\mathrm{a}}$ \\
$\mathrm{EC}(\mu \mathrm{S} / \mathrm{cm})$ & $97.24 \pm 5.6^{\mathrm{a}}$ & $112.2 \pm 15.3^{\mathrm{a}}$ & $121.5 \pm 14.9^{\mathrm{a}}$ & $110.9 \pm 6.7^{\mathrm{a}}$ & $110.3 \pm 8.4^{\mathrm{a}}$ \\
$\mathrm{TDS}(\mathrm{mg} / \mathrm{L})$ & $74.82 \pm 4.2^{\mathrm{a}}$ & $77.72 \pm 4.9^{\mathrm{a}}$ & $76.92 \pm 5.8^{\mathrm{a}}$ & $85.9 \pm 13.9^{\mathrm{a}}$ & $78.6 \pm 6.7^{\mathrm{a}}$ \\
$\mathrm{DO}(\mathrm{mg} / \mathrm{L})$ & $5.3 \pm 0.1^{\mathrm{a}}$ & $5.4 \pm 0.08^{\mathrm{a}}$ & $5.8 \pm 0.05^{\mathrm{a}}$ & $4.9 \pm 0.09^{\mathrm{a}}$ & $4.9 \pm 0.1^{\mathrm{a}}$ \\
$\mathrm{BOD5}(\mathrm{mg} / \mathrm{L})$ & $4.73 \pm 1.7^{\mathrm{a}}$ & $5.34 \pm 1.4^{\mathrm{a}}$ & $5.68 \pm 1.5^{\mathrm{a}}$ & $6.4 \pm 1.7^{\mathrm{a}}$ & $4.04 \pm 0.6^{\mathrm{a}}$ \\
$\mathrm{COD}(\mathrm{mg} / \mathrm{L})$ & $71.86 \pm 12.3^{\mathrm{a}}$ & $61.8 \pm 11.7^{\mathrm{a}}$ & $74.4 \pm 15.7^{\mathrm{a}}$ & $81.32 \pm 19.2^{\mathrm{a}}$ & $79.44 \pm 6.5^{\mathrm{a}}$ \\
Nitrate $(\mathrm{mg} / \mathrm{L})$ & $0.8 \pm 0.04^{\mathrm{a}}$ & $0.9 \pm 0.2^{\mathrm{a}}$ & $0.9 \pm 0.1^{\mathrm{a}}$ & $0.8 \pm 0.1^{\mathrm{a}}$ & $0.9 \pm 0.05^{\mathrm{a}}$ \\
Dissolved Phosphorus $(\mathrm{mg} / \mathrm{L})$ & $0.2 \pm 0.08^{\mathrm{a}}$ & $0.2 \pm 0.09^{\mathrm{a}}$ & $0.2 \pm 0.06^{\mathrm{a}}$ & $0.2 \pm 0.07^{\mathrm{a}}$ & $0.2 \pm 0.07^{\mathrm{a}}$ \\
Total Phosphorus $(\mathrm{mg} / \mathrm{L})$ & $0.183 \pm 0.03^{\mathrm{a}}$ & $0.178 \pm 0.05^{\mathrm{a}}$ & $0.155 \pm 0.03^{\mathrm{a}}$ & $0.168 \pm 0.04^{\mathrm{a}}$ & $0.161 \pm 0.05^{\mathrm{a}}$ \\
Visibility $(\mathrm{cm})$ & $91.4 \pm 11.2^{\mathrm{a}}$ & $88.5 \pm 3.3^{\mathrm{a}}$ & $86.6 \pm 4.8^{\mathrm{a}}$ & $87.1 \pm 3.9^{\mathrm{a}}$ & $84.1 \pm 5.1^{\mathrm{a}}$ \\
\hline
\end{tabular}

Table 4 Spatial variation of sediment quality parameters in the study sites of the Ja-Ela stream $(n=9)$. Results are presented as mean \pm standard deviation. Different superscripts in each row indicate statistically significant differences (One way ANOVA, Tukey's pairwise test; $p<0.05$ ). Site 1: Undisturbed site; Site 2: Agricultural site; Site 3: Industrial site; Site 4: Urban site; Site 5: Mouth of the stream

\begin{tabular}{lccccc}
\hline & Site 1 & Site 2 & Site 3 & Site 4 & Site 5 \\
\hline \% TOC & $37.1 \pm 0.6^{\mathrm{a}}$ & $43.2 \pm 4.8^{\mathrm{a}}$ & $53.9 \pm 1.7^{\mathrm{b}}$ & $56.3 \pm 3.1^{\mathrm{b}}$ & $51.4 \pm 2.2^{\mathrm{b}}$ \\
Sediment pH & $5.8 \pm 0.2^{\mathrm{a}}$ & $5.9 \pm 0.1^{\mathrm{a}}$ & $5.5 \pm 0.5^{\mathrm{a}}$ & $5.6 \pm 0.4^{\mathrm{a}}$ & $5.1 \pm 0.4^{\mathrm{a}}$ \\
\%sand & $82.9 \pm 0.2^{\mathrm{a}}$ & $80.8 \pm 0.6^{\mathrm{a}}$ & $72.1 \pm 0.8^{\mathrm{b}}$ & $74.6 \pm 0.6^{\mathrm{b}}$ & $73.2 \pm 0.6^{\mathrm{b}}$ \\
\% Silt & $8.7 \pm 0.1^{\mathrm{a}}$ & $9.7 \pm 1.4^{\mathrm{a}}$ & $14.2 \pm 1.8^{\mathrm{b}}$ & $15.1 \pm 1.5^{\mathrm{b}}$ & $13.9 \pm 1.1^{\mathrm{b}}$ \\
\% clay & $8.4 \pm 1.2^{\mathrm{a}}$ & $9.7 \pm 1.5^{\mathrm{a}}$ & $13.8 \pm 1.7^{\mathrm{b}}$ & $12.7 \pm 1.2^{\mathrm{b}}$ & $12.9 \pm 1.2^{\mathrm{b}}$ \\
\hline
\end{tabular}

Table 5 Spatial variation of sediment quality parameters in the study sites of the Ja-Ela stream $(n=9)$. Results are presented as mean \pm standard deviation. Similar superscripts in each row indicate that there was no statistically significant temporal variation in the water quality parameters throughout the study period (One way ANOVA, Tukey’s pairwise test; $\mathrm{p}<0.05$ )

\begin{tabular}{lccccc}
\hline & April & May & July & August & October \\
\hline \%TOC & $46.71 \pm 1.6^{\mathrm{a}}$ & $48.2 \pm 3.8^{\mathrm{a}}$ & $47.7 \pm 3.7^{\mathrm{a}}$ & $46.3 \pm 4.1^{\mathrm{a}}$ & $47.4 \pm 4.2^{\mathrm{a}}$ \\
Sediment pH & $5.7 \pm 0.2^{\mathrm{a}}$ & $5.9 \pm 0.1^{\mathrm{a}}$ & $5.7 \pm 0.5^{\mathrm{a}}$ & $5.7 \pm 0.4^{\mathrm{a}}$ & $5.6 \pm 0.4^{\mathrm{a}}$ \\
\% Sand & $89.8 \pm 3.5^{\mathrm{a}}$ & $82.5 \pm 4.6^{\mathrm{a}}$ & $82.1 \pm 5.8^{\mathrm{a}}$ & $84.8 \pm 2.6^{\mathrm{a}}$ & $83.2 \pm 5.6^{\mathrm{a}}$ \\
\% Silt & $4.2 \pm 2.1^{\mathrm{a}}$ & $4.7 \pm 2.4^{\mathrm{a}}$ & $4.2 \pm 1.8^{\mathrm{a}}$ & $5.1 \pm 3.5^{\mathrm{a}}$ & $3.9 \pm 5.1^{\mathrm{a}}$ \\
\% Clay & $6.05 \pm 4.2^{\mathrm{a}}$ & $12.8 \pm 5.5^{\mathrm{a}}$ & $13.7 \pm 4.7^{\mathrm{a}}$ & $10.1 \pm 4.2^{\mathrm{a}}$ & $12.9 \pm 6.2^{\mathrm{a}}$ \\
\hline
\end{tabular}

Total number of benthic macro invertebrates per $\mathrm{m}^{2}$ recorded from each of the five sampling sites of Ja-Ela stream during the study period is given in Table 6. Altogether 16 families of benthic macroinvertebrates belonging to three phyla were recorded during the study period. Among them two families were of Phylum Annelida, 5 families were of Phylum Mollusca and 9 families were of Phylum Arthropoda (Table 6). The most abundant species in all sites was Pila globosa, except in the urban site, which was dominated by Lymnaea pinguis. Tubifex sp. was present in all the study sites except in the 
undisturbed site and was recorded in significantly higher value in the urban site (Table 6).

The mean values for Shannon-Weiner Diversity index $\left(\mathrm{H}^{\prime}\right)$, Hilsenhoff Family Biotic index (FBI), Taxa richness (TR) and EPT index for each sampling site are given in Table 7 . The highest values for H', TR and EPT were recorded from the undisturbed site. Significantly higher FBI values were recorded from the industrial site and the urban site, indicating that they are most significantly polluted sites with higher degree of organic pollution (Table 7). The criteria for water quality classification based on FBI is given in Table 8. According to this classification, the water quality of the undisturbed site could be classified as "fair" while that of the other sites could be classified as "poor" (Table 8).

Table 6 Abundance of benthic macroinvertebrates (number per $\mathrm{m}^{2}$ ) in the study sites of Ja-Ela stream during the sampling period. Site 1: Undisturbed site; Site 2: Agricultural site; Site 3: Industrial site; Site 4: Urban site; Site 5: Mouth of the stream

\begin{tabular}{|c|c|c|c|c|c|c|c|c|c|c|c|}
\hline Macroinvertebrate & $\begin{array}{c}\text { Site } \\
1\end{array}$ & $\begin{array}{c}\text { Site } \\
2\end{array}$ & $\begin{array}{c}\text { Site } \\
3\end{array}$ & $\begin{array}{c}\text { Site } \\
4\end{array}$ & $\begin{array}{c}\text { Site } \\
5\end{array}$ & Macroinvertebrate & $\begin{array}{c}\text { Site } \\
1\end{array}$ & $\begin{array}{c}\text { Site } \\
2\end{array}$ & $\begin{array}{c}\text { Site } \\
3\end{array}$ & $\begin{array}{c}\text { Site } \\
4\end{array}$ & $\begin{array}{c}\text { Site } \\
5\end{array}$ \\
\hline Annelida & & & & & & Arthropoda & & & & & \\
\hline Tubificidae & & & & & & Tabanidae & & & & & \\
\hline $\begin{array}{l}\text { Tubifex sp } \\
\text { Naididae }\end{array}$ & 0 & 16 & 62 & 138 & 18 & $\begin{array}{l}\text { Chironomus sp } \\
\text { Ceratopogonidae }\end{array}$ & 12 & 17 & 76 & 114 & 27 \\
\hline Species 1 & 16 & 17 & 56 & 65 & 15 & $\begin{array}{l}\text { Culicoides sp } \\
\text { Biting midge larvae }\end{array}$ & 55 & 111 & 71 & 34 & 50 \\
\hline Naididae & & & & & & Order- Ephemeroptera & & & & & \\
\hline Species 2 & 30 & 22 & 82 & 65 & 13 & $\begin{array}{l}\text { Family- Baetidae } \\
\text { Baetis sp. }\end{array}$ & 39 & 4 & 0 & 0 & 12 \\
\hline Mollusca & & & & & & $\begin{array}{l}\text { Order- Ephemeroptera } \\
\text { Family- Leptophlebiidae }\end{array}$ & & & & & \\
\hline Pilidae & & & & & & $\begin{array}{l}\text { Leptophlebia sp. } \\
\text { Order- Odonata }\end{array}$ & 16 & 1 & 0 & 0 & 4 \\
\hline Pila globosa & 107 & 134 & 159 & 147 & 163 & $\begin{array}{l}\text { Family- Coenagrionidae } \\
\text { Coenagrion sp. }\end{array}$ & 25 & 8 & 4 & 3 & 5 \\
\hline Thiaridae & & & & & & Order- Plecoptera & & & & & \\
\hline Melanoides tuberculata & 23 & 97 & 64 & 197 & 113 & $\begin{array}{l}\text { Family- Perlidae } \\
\text { Neoerla } \text { sp. }\end{array}$ & 14 & 0 & 0 & 0 & 10 \\
\hline Thiaridae & & & & & & Order-Trichoptera & & & & & \\
\hline Faunus ater & 19 & 83 & 18 & 19 & 33 & $\begin{array}{l}\text { Family- Hydropsychidae } \\
\text { Hydroptilla } \text { sp. }\end{array}$ & 23 & 4 & 0 & 0 & 0 \\
\hline Lymnaeidae & & & & & & Order-Trichoptera & & & & & \\
\hline Lymnaea pinguis & 77 & 64 & 144 & 217 & 94 & $\begin{array}{l}\text { Family- Helicopsychidae } \\
\text { Helicopsyche } \text { sp. }\end{array}$ & 17 & 0 & 2 & 0 & 1 \\
\hline $\begin{array}{l}\text { Planorbidae } \\
\text { Indoplanorbis exustus }\end{array}$ & 39 & 89 & 115 & 114 & 6 & $\begin{array}{l}\text { Order - Coleoptera } \\
\text { Family - Psephenidae } \\
\text { Psephenus sp. }\end{array}$ & 10 & 2 & 0 & 0 & 4 \\
\hline $\begin{array}{l}\text { Paludestrinidae } \\
\text { Bithynia inconspicua }\end{array}$ & 24 & 23 & 21 & 74 & 22 & & & & & & \\
\hline
\end{tabular}


Table 7 The mean \pm standard deviation values of Shannon-Weiner Diversity index ( $\left.\mathrm{H}^{`}\right)$, Hilsenhoff Family Biotic index (FBI), Taxa richness (TR) and EPT index for the benthic macroinvertebrates in the study sites $(\mathrm{n}=9)$. Different superscripts in each column indicate statistically significant differences (One way ANOVA, Tukey's pairwise test; $\mathrm{p}<0.05$ ). Site 1: Undisturbed site; Site 2: Agricultural site; Site 3: Industrial site; Site 4: Urban site; Site 5: Mouth of the stream

\begin{tabular}{ccccc}
\hline Site & H & FBI & TR & EPT \\
\hline Site 1 & $2.38 \pm 0.02^{\mathrm{a}}$ & $6.17 \pm 0.1^{\mathrm{a}}$ & $13.60 \pm 0.3^{\mathrm{a}}$ & $6.20 \pm 0.1^{\mathrm{a}}$ \\
Site 2 & $1.97 \pm 0.01^{\mathrm{b}}$ & $6.67 \pm 0.2^{\mathrm{a}}$ & $9.20 \pm 0.1^{\mathrm{b}}$ & $1.40 \pm 0.3^{\mathrm{b}}$ \\
Site 3 & $1.96 \pm 0.02^{\mathrm{b}}$ & $6.97 \pm 0.2^{\mathrm{b}}$ & $8.40 \pm 0.3^{\mathrm{b}}$ & $0.60 \pm 0.3^{\mathrm{b}}$ \\
Site 4 & $2.06 \pm 0.02^{\mathrm{b}}$ & $6.81 \pm 0.2^{\mathrm{b}}$ & $8.60 \pm 0.2^{\mathrm{b}}$ & $0.20 \pm 0.2^{\mathrm{b}}$ \\
Site 5 & $1.88 \pm 0.01^{\mathrm{b}}$ & $6.58 \pm 0.1^{\mathrm{a}}$ & $9.00 \pm 0.2^{\mathrm{b}}$ & $2.20 \pm 0.2^{\mathrm{b}}$ \\
\hline
\end{tabular}

Table 8 Criteria for evaluation of water quality using the family-level biotic index (Hilsenhoff 1988)

\begin{tabular}{ccl}
\hline Biotic index Value & Water quality & \multicolumn{1}{c}{ Degree of organic pollution } \\
\hline $0.00-3.50$ & Excellent & No apparent organic pollution \\
$3.51-4.50$ & Very good & Possible slight organic pollution \\
$4.51-5.50$ & Good & Some organic pollution \\
$5.51-6.50$ & Fair & Fairly significant organic pollution \\
$6.51-7.50$ & Fairly poor & Significant organic pollution \\
$7.51-8.50$ & Poor & Very significant organic pollution \\
$8.50-10.0$ & Very poor & Severe organic pollution \\
\hline
\end{tabular}

In the Principal Component Analysis of water and sediment quality parameters, the first two principal components (PC1 and PC2) accounted for $82.3 \%$ cumulative variance (Table 9). PCA score plot and the factor loading plot for variation of water quality and sediment quality parameters among the five sites of Ja-Ela stream is shown in Figure 2. The eigenvalues of the first two principal components, eigenvectors of the water and sediment quality variables for the study sites are given in Table 9.

The results of the PCA analysis revealed that the undisturbed site is characterized by higher visibility and higher percentage sand content in the sediments. The industrial site and the site at the mouth of the stream were clustered at the upper left hand corner of the PCA plot and according to the factor loadings, these sites were characterized by high percentage clay content and high percentage total organic carbon content (Figure 2, Table 9). The agricultural site was characterized by high total phosphorous content. The urban site was located at the bottom left hand corner of the PCA plot and was characterized by high total dissolved solids, high $\mathrm{BOD}_{5}$, high electrical conductivity and high temperature (Fig. 2, Table 9). However, the results of PCA showed that the industrial site and the site at the mouth of the stream shared common sediment and water quality characteristics compared to the other sites.

The results of the linear regression analysis of benthic macro invertebrate index values and PC score 1 of sediment and water quality characteristics are given in Figure 3. Coefficients of determination $\left(\mathrm{R}^{2}\right)$ being greater than 0.5 indicated a strong relationship between the variables. Therefore, according to the results, the Shannon-Weiner Diversity index $\left(\mathrm{H}^{\prime}\right)$, Hilsenhoff Family Biotic index (FBI), Taxa richness (TR) and EPT index showed strong relationships with the PC 1 score (Fig. 3). 
Table 9 Summary of the PCA of water and sediment quality parameters of the five study sites. Cumulative \% variation of only the PC1 and PC2 are shown.

\begin{tabular}{lcc}
\hline & PC1 & PC2 \\
\hline Eigenvalue & 7.56 & 5.60 \\
\%Variance & 47.2 & 35.0 \\
Cum.\%Variance & 47.2 & 82.2 \\
Eigenvectors & & \\
Variable & PC1 & PC2 \\
Water pH & -0.121 & 0.376 \\
Temperature & -0.099 & -0.356 \\
Electrical Conductivity & -0.186 & -0.356 \\
Total Dissolved Solids & -0.166 & -0.366 \\
Dissolved Oxygen & 0.067 & 0.346 \\
BOD & -0.278 & -0.242 \\
COD & -0.284 & 0.087 \\
Nitrate & -0.070 & 0.389 \\
Dissolved Phosphorus & -0.300 & 0.010 \\
Total Phosphorus & 0.007 & 0.224 \\
Visibility & 0.310 & -0.146 \\
\%TOC & -0.328 & 0.180 \\
Sediment pH & 0.255 & -0.140 \\
\% Sand & 0.359 & -0.050 \\
\% Silt & -0.359 & -0.062 \\
\% Clay & -0.360 & 0.052 \\
\hline
\end{tabular}

(a)

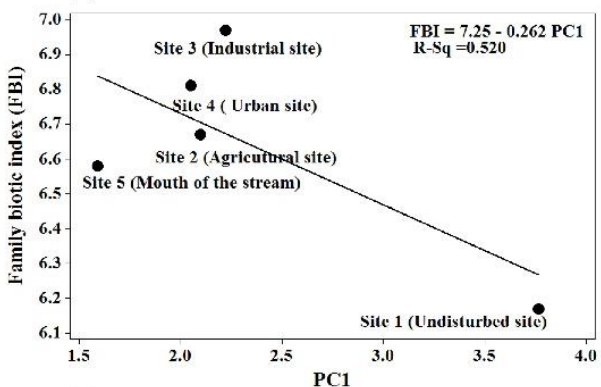

(c)

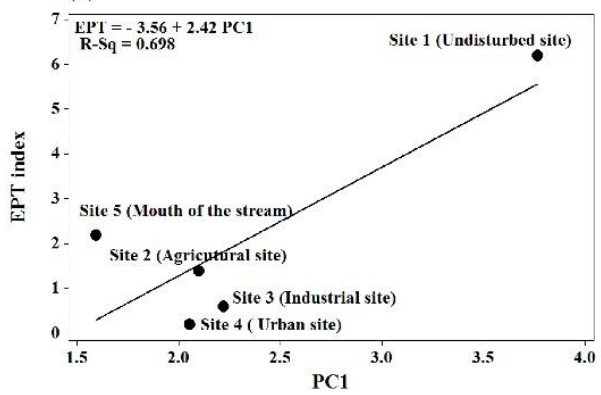

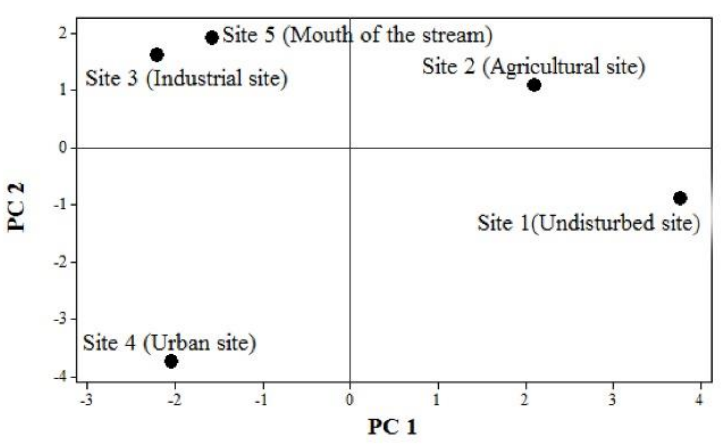

Fig. 2 Ordination of the five study sites based on PC1 and PC2 scores of PCA of the physicochemical parameters of water and sediments of the Ja Ela canal. (b)

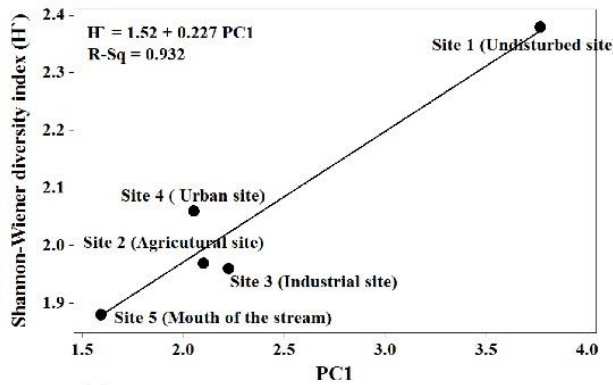

(d)

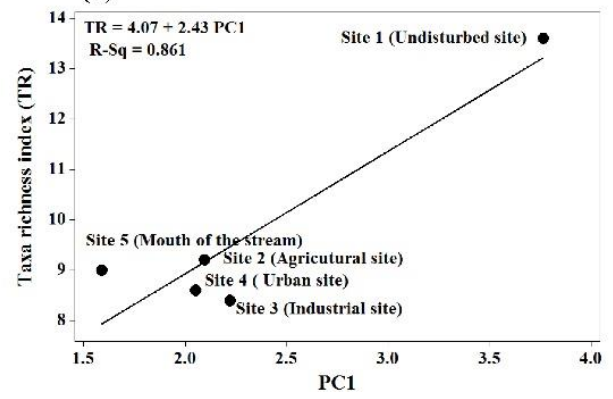

Fig. 3 Linear regression of biotic indices used in Rapid Bioassessment Protocol II of the five study sites against the PC1 score for physico-chemical parameters of the sediments and overlying water. (a) Family Biotic Index; (b) Shannon Wiener diversity index; (c) EPT Index; (d) Taxa Richness index 


\section{DISCUSSION}

According to the proposed ambient water quality standards published by the Central Environmental Authority of Sri Lanka, in inland waters of Sri Lanka, the total nitrate concentration should be $\leq 5$ $\mathrm{mg} / \mathrm{L}$, total phosphorous (TP) concentration should be $\leq 0.4 \mathrm{mg} / \mathrm{L}$, dissolved oxygen content should be $\geq 3 \mathrm{mg} / \mathrm{L}$ and $\mathrm{pH}$ should be within 6-8.5 in order to maintain healthy aquatic life (CEA 2001). In the present study, the TP concentration of the agricultural and industrial sites was above the required ambient level for maintaining healthy aquatic life. However, nitrate concentration, $\mathrm{pH}$ and dissolved oxygen of these sites were favorable to sustain aquatic life. In the sediments, there was a decreasing trend of percentage sand content and increasing trend of percentage clay, silt and total organic carbon content from upstream to downstream areas. This can be due to the reduced flow rate and increased amount of sediment load carried by the stream as it flows downstream as reported for lotic wetlands in many regions of the world (Bravard et al. 2014; Csiki and Rhoads 2014; Yang et al. 2014).

All the annelids recorded in the present study were of Class Oligochaeta which is considered as pollution tolerant class (Sarang and Sharma 2009). Tubificids and Naidids of this class are considered as highly pollution tolerant species as they can withstand considerable depletion of dissolved oxygen in the environment (Sarang and Sharma 2009). High abundance of the tubificids and naidids were recorded in urban site and in industrial site which had high $\mathrm{BOD}_{5}$ and $\mathrm{COD}$. In addition to the ability to tolerate harsh conditions, individuals of both these taxa are able to penetrate deep into the sediments and therefore, prefer the substrates with high clay percentage (Sarang and Sharma 2009). As the undisturbed site was characterized with high sand content and low pollution, tubificids and naidids were less abundant in this site.

Of the five families of Phylum Mollusca recorded during the present study, members of Family Pilidae were the most abundant in the industrial site, urban site and the site near the mouth of the stream while the members of Family Thiridae were most abundant at the latter two sites. These two families are considered to be pollution tolerant taxa and they prefer stagnant or slow flowing water with high clay, silt and organic matter contents
(Fernando and Weerawardhena 2002). The industrial site, urban site and the site near the mouth of the stream were characterized by high clay and silt contents. Therefore, these sites may be providing ideal habitats for the members of Families Pilidae and Thiaridae. The undisturbed site showed a comparatively low abundance of the members of Families Pilidae and Tharidae, perhaps due to the high flow rate and low percentage of clay and silt in the sediments.

Members representing other molluscan families, Family Lymnaeidae, Family Planorbidae and Family Paludestrinidae showed highest abundance at the urban site. This site is located near the Ja-Ela town which is highly urbanized and populated. Waste water from many hotels, small businesses and households is discharged and large amount of solid waste is dumped into the stream in this area. Several storm water outlets from the town also drain into the stream in this area. This may be the reason for the highest organic matter content in this site (Table 2). Due to this high organic matter content, this site is characterized by high $\mathrm{BOD}_{5}$ and high total dissolved solids (TDS) in this site (Table 2). The members of the molluscan families Lymnaeidae, Planorbidae and Paludestrinidae prefer substrates with high decaying organic matter (Fernando and Weerawardhena 2002). The high input of organic matter as waste water and solid waste may be contributing high content of decaying organic material and thereby may be providing ideal habitats for the representatives of above families at the urban site.

Abundance of some members of Phylum Arthropoda is significantly important in freshwater ecosystems because majority of them are pollution sensitive taxa (Barbour et al. 1999). Therefore, they act as the best indicators of the water quality in freshwater ecosystems. Nine families of arthropods were recorded from the sampling sites during the study period. Among them Tabanidae and Ceratopogonidae were the families that are pollution tolerant (Barbour et al. 1999). Chironomus species (Family Tabanidae) are usually recorded in a freshwater system with degraded water quality due to organic pollution (Sarang and Sharma 2009). The urban site which had highest level of $\mathrm{BOD}_{5}$ due to organic pollution showed the highest abundance of Chironomid larvae indicating that Chironomid species are good indicators of organic pollution of the Ja-Ela stream as well. Presence of Chironomid 
larvae had also been observed in highly organically polluted sites in the Bolgoda canal in Sri Lanka and are identified as ideal indications of unclean water where organic pollution is high and dissolved oxygen content is low (Idroos and Manage 2012).

Members of five families belonging to order Ephemeroptera, Plecoptera and Trichoptera were recorded during the present study. All these families showed highest abundance in the undisturbed site. The members of these orders are highly pollution sensitive and therefore are absent in severely polluted waters (Kripa et al. 2013). Hence, these orders were completely absent in the urban site. However, members of one Trichopteran family was recorded in the industrial site, that too at very low abundance.

Members of one Coleopteran family and one Odonata family were also recorded during the study. Aquatic coleopterans are considered as pollution sensitive (Kripa et al. 2012) and they showed high abundance only in the undisturbed site. odonates are considered as a moderately pollution tolerant group and they are reported to be capable of tolerating low oxygen levels and organic pollution (Kripa et al. 2013). This could be the reason for them to be recorded in lower abundance in the industrial and urban sites and also near the mouth of the stream.

Significantly higher values for H', EPT and TR were recorded for the undisturbed site indicating a significantly higher benthic macroinvertebrate diversity compared to other sites. Significantly higher values for EPT index in the undisturbed site indicated that site was dominated by pollution sensitive families while other indices suggested that sites with higher level of pollution were dominated by more pollution tolerant taxa. The categorization of sites according to FBI is much more similar to the characterization of sites according to their water quality parameters and sediment characteristics. Significantly higher FBI values were recorded from the industrial site and the urban site, indicating that they are the most polluted sites with high degree of organic pollution (Table 8).

Several studies have confirmed that the biotic indices show significant relationships to water and sediment quality parameters of inland water bodies. Total nitrogen, total phosphorous, temperature, dissolved oxygen and biological oxygen demand has shown significant influences on the species diversity, dominance and richness of macroinvertebrates in Lake Victoria Basin, Kenya
(Ngodhe et al. 2014) and in Ebro River Basin, Spain (Leunda et al. 2009). Studies on the relationships between biotic indices and water quality parameters are not common in the inland waters of Sri Lanka. In a study conducted in the Colombo-Sri Jayewardenepura Canal System, 'Reference' and 'Degraded' sampling sites have been identified based on the environmental conditions and macroinvertebrates and a Macroinvertebrate-based Index of Biotic Integrity (M-IBI) has been developed to monitor stream/wetland health (Perera et al. 2012). In this study, H', EPT, FBI and TR have been found to be significantly correlated with water quality parameters such as dissolved oxygen concentration, $\mathrm{Cl}^{-}$concentration, total dissolved solids and conductivity. In a stream habitat at Dediyagala, Sri Lanka, significant correlations between dissolved oxygen concentration and Shannon-Wiener diversity index of benthic macroinvertebrates has been reported by Madushanka et al. (2014). Significant effects of dissolved oxygen, nitrate concentration and biological oxygen demand on the pollution tolerance index of benthic macroinvertebrates in Bolgoda canal and Waga stream in Colombo have also been reported (Idroos and Manage 2012).

The results of the PCA showed that the biotic indices used in RBP II have a good relationship with water and sediment quality characteristics of the study sites $\left(\mathrm{R}^{2}>0.5\right)$ confirming that these biotic indices can be successfully used to assess the water quality in the Ja-Ela stream. Values for H', EPT, FBI and TR indices confirmed that the upstream portion of the Ja-Ela stream is inhabited by pollution sensitive taxa, while the downstream areas are inhabited by pollution tolerant taxa. The present study indicated that the rapid bioassessment protocol can be used as a bio-monitoring protocol to reflect the water and sediment quality in the Ja-Ela stream.

\section{REFERENCES}

APHA 1992. Standard methods for the examination of water and wastewater (18th Ed.). American Public Health Association, American Water works Association, Water Environment Federation Publcation. Washington D.C. 1198 p. Barbour M.T., J. Gerritsen, B.D. Snyder and J.B. Stribling 1999. Rapid bioassessment protocols for use in streams and wadeable rivers: 
Periphyton, benthic macroinvertebrates and fish, Second Edition. EPA 841-B-99-002. U.S. Environmental Protection Agency, Office of Water, Washington, D.C. 344p.

Bravard J.P., M. Goichot and H. Tronchère 2014. An assessment of sediment-transport processes in the Lower Mekong River based on deposit grain sizes, the CM technique and flow energy data. Geomorphology 207: 174-189.

doi: 10.1016/j.geomorph.2013.11.004

CEA 2001. Proposed Ambient Water quality Standards for Inland Waters in Sri Lanka. Environment Action 1 Project (Funded by ADB), Central Environmental Authority, Colombo, Sri Lanka.

Chessman B.C. 1995. Rapid assessment of rivers using macroinvertebrates: A procedure based on habitat-specific sampling, family level identification and a biotic index. Australian Journal of Ecology 20: 122-129. doi:10.1111/j.1442-9993.1995.tb00526.x

Csiki S.J.C. and B.L. Rhoads 2014. Influence of four run-of-river dams on channel morphology and sediment characteristics in Illinois, USA. Geomorphology 206: 215-229. doi:10.1016/j.geomorph.2013.10.009

Dahanayaka D.D.G.L. and M.J.S. Wijeyaratne 2006. Diversity of macrobenthic community in the Negombo estuary, Sri Lanka with special reference to environmental conditions. Sri Lanka Journal of Aquatic Sciences 11: 43-61. doi: 10.4038/sljas.v11i0.2222

Emere M.C. and C.E. Nasiru 2008. Macroinvertebrates as indicators of the water quality of an urbanized stream, Kaduna Nigeria. Nature and Science 6: 1-7.

Fernando C.H. and S.R. Weerawardhena 2002. A guide to the fresh water fauna of Ceylon (Sri Lanka). A reprint of A. S. Mendis and C. H. Fernando (1962) with a forward, a check list of Amphibians of Sri Lanka and selected references on freshwater fauna. ISBN 955-97936-0-8. 173 p.

Gamlath G.A.R.K and M.J.S. Wijeyaratne 1997. Indicator organisms of environmental conditions in a lotic water body in Sri Lanka. Sri Lanka Journal of Aquatic Sciences 2: 121-129.

Goldstein R.E. 2011. Effectiveness of macroinvertebrate-based biotic Indexes in assessing stream water quality in Sycamore Creek, IN, Bachelors of Science Environmental
Science Senior Thesis, Indiana University Bloomington. http://www.indiana.edu/ preserve/docs/library/ goldstein2011.pdf [accessed 3 April 2015]

Guruge W.A.H.P., N.J. De S. Amarasinghe and C.H Priyantha 2003. Application of Rapid Bioassesment Protocol (RBP)-II for evaluation of water quality in headstreams of Nilwala river basin in Sri Lanka. Proceedings of the academic sessions, University of Ruhuna 1: 148-152.

Hilsenhoff W.L. 1988. Using a biotic index to evaluate water quality in streams. Technical Bulletin of Wisconsin Department of Natural Resources 132p.

Idroos F.S. and P.M. Manage 2012. Aquatic life health quality assessment of the Bolgoda Canal and Waga Stream with respect to selected physico-chemical parameters and bioindicators. Journal of Tropical Forestry and Environment 2(2): 13-26.

Kripa P.K., K.M. Prasanth, K.K. Sreejesh and T.P. Thomas 2013. Aquatic macroinvertebrates as bioindicators of stream water quality-A Case study in Koratty, Kerala, India. Research Journal of Recent Sciences 2: 217-222.

Lewin I., I. Czerniawska-Kusza, K. Szoszkiewicz, A.E. Ławniczak and S. Jusik 2013. Biological indices applied to benthic macroinvertebrates at reference conditions of mountain streams in two ecoregions (Poland, the Slovak Republic). Hydrobiologia 709(1): 183-200.

doi: 10.1007/s10750-013-1448-2

Leunda P. M., J. Oscoz, R. Miranda and A.H. Arinõ 2009. Longitudinal and seasonal variation of the benthic macroinvertebrate community and biotic indices in an undisturbed Pyrenean river. Ecological Indicators 9: 52-63. doi:10.1016/j.ecolind.2008.01.009

Madhushanka, H.M.T.C, H.B. Asanthi and R.A. Maithreepala 2014. The benthic macroinvertebrate diversity in relation to water quality of a stream habitat at Dediyagala, Sri Lanka. Sri Lanka Journal of Aquatic Sciences 19: 15-29. doi: http://doi.org/10.4038/sljas.v19i0.7448

Mandaville S.M. 2002. Benthic macroinvertebrates in freshwaters: Taxa tolerance values, metrics, and protocols. Soil \& Water Conservation Society of Metro Halifax, Halifax, Canada. $128 \mathrm{p}$.

Murugesan P. and S.A. Khan 2007. Coastal Biodiversity in Mangrove Ecosystems, UNU- 
INWEH-UNESCO International Training Course (November 12-26), UNU-INWEH United Nations University International Network on Water, Environment \& Health, Canada, United Nations Educational Scientific and Cultural Organization, Jakarta Indonesia, Man and Biosphere, Japanese Funds-in-Trust, Annamalai University, Tamil Nadu, India, pp 294-303.

Perera R., J. Wattavidanage and N. Nilakarawasam 2012. Development of a Macroinvertebratebased Index of Biotic Integrity (M-IBI) for Colombo-Sri Jayawardhanapura Canal System (A new approach to assess stream/wetland health). Journal of Tropical Forestry and Environment 2(1): 10-19.

Sangakkara S.M.A.I. and M.J.S. Wijeyaratne 2015. Community structure of zooplankton and trophic status of some inland reservoirs in the low country intermediate zone of Sri Lanka. Sri Lanka Journal of Aquatic Sciences 20(2): 59-74. doi: http://doi.org/10.4038/sljas.v20i2.7479

Sarang N. and L.L. Sharma 2009. Macrobenthic fauna as bioindicators of water quality in Kishore Sagar Lake, Kota (Rajasthan) India. 13th Conference Wuhan 2009, Conference Papers. Wuhan. 57-77.

Ngodhe S. O., P. O. Raburu and A. Achieng 2014. The impact of water quality on species diversity and richness of macroinvertebrates in small water bodies in Lake Victoria Basin, Kenya. Journal of Ecology and the Natural Environment 6(1): 32-34. doi: 10.5897/JENE2013.0403

Uyanik S., G. Yilmaz, M.I. Yesilnacar, M. Aslan and O. Demir 2005. Rapid assessment of river water quality in Turkey using benthic macroinvertebrates. Fresenius Environmental Bulletin 14(4): 268-272.

Wijeyaratne W.M.D.N. 2016. Application of pollution indices to quantify the pollution status of shallow sediments of the Bolgoda Lake, Sri Lanka. Journal of National Science Foundation of Sri Lanka 44(3): 279-289.

doi: http://dx.doi.org/10.4038/jnsfsr.v44i3.8010

Wijeyaratne W.M.D.N and A. Pathiratne 2006. Acetylcholinesterase inhibition and gill lesions in Rasbora caverii, an indigenous fish inhabiting rice field associated water-bodies in Sri Lanka. Ecotoxicology 15(7): 609-619. doi: https://doi.org/10.1007/s10646-006-0101-5
Yang S.L., J.D. Milliman, K.H. Xu, B. Deng, X.Y. Zhang and X.X. Luo 2014. Downstream sedimentary and geomorphic impacts of the Three Gorges Dam on the Yangtze River. Earth Sciences Reviews 138: 469-486. doi:http://dx.doi.org/10.1016/j.earscirev.2014.0 7.006 